\title{
Classic Elegant Style Preference in Indonesian Upper-Class Customers in 2015-2018
}

\author{
Tyar Ratuannisa ${ }^{1}$, Kahfiati Kahdar ${ }^{2}$, Asyifa Rachmadina J. $^{3}$, Annisaa \\ Nurfitriyana $^{4}$ \\ 1,2,3 Craft and Tradition Research Group, Faculty of Visual Art and Design, Institut \\ Teknologi Bandung \\ ${ }^{4}$ Master of Design Study Program, Faculty of Visual Art and Design, Institut \\ Teknologi Bandung \\ tyar@fsrd.itb.ac.id, kahfiati@fssrd.itb.ac.id., asyifa@fsrd.itb.ac.id, \\ annisaa.nurfitriyana@students.itb.ac.id,
}

\begin{abstract}
Clothes do not only fulfill physiological needs, but also psychological needs, so that humans look stylish and trendy. One style of clothes that is recognized and used in Indonesia is a classic elegant style that is characterized by neat cuts, tailor made, and a choice of colors and motifs that tend not too extravagant to accentuate the neat and classic pieces. The use of classic elegant style by upper-class consumers as an important role of the trickle-down fashion principle in this research was traced from the rubrics of "Hot" and "Liputan Khusus" in Dewi Magazine published in 2015-2018. It was found that this style was the dominant style that emerged along with the repetitive cycle of 1980s fashion trends in which fashion consumers had the desire to look established, exclusive, and had special attention to a healthy lifestyle that made the wearers look fit and prime. In the past, classic elegant style was more widely used by adult upper-class consumers, however, the stereotypes changed since this style was then used by young adults with various professions related to the use of the internet, which led to the shifting of upper-class consumers into young adults.
\end{abstract}

Keywords: Fashion style, Classic elegant, Upper-class consumers, Dewi Magazine

\section{INTRODUCTION}

Human needs to dress in principle to meet the secondary needs, but along with the civilization development, human also develops other needs that are met by clothes in addition to its body protection principle. Humans dress themselves to be stylish [1]. In Indonesia, it is known that the habit of dressing for aesthetic needs has developed since the $14^{\text {th }}$ century, which is enshrined in the reliefs of the Borobudur temple that shows the clothes variety according to the needs of its user activities [2]. In the next era, fashion styles in Indonesia followed the trend of Western clothes with the use of modern clothes by Indonesian women, such as dresses, blouses, skirts, and pants, which shifted from the use of kebaya and sarong 
that was originally referred to as typical clothes for Indonesian women. The use of modern clothes in Indonesia continues to grow until now, by bringing up a variety of fashion styles that refer to world fashion trends. One of the clothing styles is widely recognized in Indonesia is the classic elegant style.

Principally, the classic elegant style, as referred to Mohamad Alim Zaman, is a style with a neat and tailor-made impression, consisting of two to three pieces of clothes that are combined and matched, the motif chosen is simple geometric like regular lines and squares, and the distinctive color is black, beige, ash, brown, maroon, and purplish shades [3]. The material used is superior quality material with a character that is not too rigid but not too thin with a silhouette that does not form the body shape. This classic elegant style is a style that is often chosen by fashion users in Indonesia for formal occasions and as a personal style. Academic research related to changes in certain fashion styles in Indonesia is still rarely found, usually academic research is more about the latest trends or trends. In the field of marketing, fashion is often a topic of study in terms of consumer behavior, trends and sales cycles and lifestyle trends in a particular community or population. However, research on fashion styles that arises over certain phenomena that utilize data from specific print media, namely fashion magazines, is rarely found at any time, and therefore this research tries to fill that gap.

Roach and Eicher stated that fashion symbolically binds a community [1], this can also be seen from the data referenced to the classic elegant style obtained from Dewi Magazine as a women's magazine emphasizing on original Indonesian fashion. The use of classic elegant clothes shows the demographic segmentation of its users, namely upper-class consumers, which is in accordance with Barnard's statement that fashion can define one's social role [4]. This research used visual data in the form of fashion content obtained from Dewi Magazine in 2015-2018 from several selected editions representing information on the use of classic elegant style.

\section{RESEARCH METHOD}

This research approaches the topic using content analysis method with visual data objects from Dewi Magazine. Content analysis was used in seeing trends and changes in objects. Content analysis is a research technique that is used to obtain an objective, systematic, and quantitative description, and it builds a form of content from communication [5]. In content analysis, systematic observation is carried out on a message based on procedural arguments and theoretical references, and validity is considered higher than reliability [6].

Dewi Magazine is an original Indonesian magazine published by Femina Group. In 1970, Pia Alisjahbana together with Mirtati Kartohadiprodjo and Widarti Gunawan published Femina Magazine, followed by Gadis Magazine and Dewi Magazine. The contents of Dewi Magazine that is specifically used in this research are visual data from two magazine rubrics, namely Hot and Liputan Khusus (Special Coverage). Those two rubrics are event coverage that are attended by high-class fashion consumers. Regarding the trickle-down pattern adopted by fashion, magazines as a media have a position between designers/elite consumers and consumers in general, as follows:

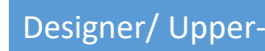

class Customer
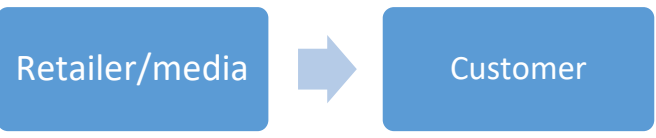

Fig. 1 Trickle-down pattern in fashion [7] 
The magazine's position in that process is an information medium for designers and elite consumers.. Trickle-down theory has a basic principle that fashion moves first in the upper social class, when a trend is introduced by a designer or trend forecaster as an agent of reforming the trend and then first adopted by upper class or elite consumers. High-end consumers are usually attached to the image of consumers with high experience needs of goods from authentic brands [8]. These consumers want to keep up to date with the latest trends, this aspect of consumerism is of paramount importance to them. They seek variety and derive a sense of pleasure when they find a new style [9].

People adopt the fashion trends of higher status locations to a far greater extant than they do lower status locations[10]. These upper-class consumers form the image of prosperity, luxury, and visual attractiveness of the attributes of the trend to lure consumers in the lower social class to imitate the style and the adoption of the latest style.

\section{RESULT AND DISCUSSION}

\section{A. Classic Elegant Style in 2015-2018}

This research has developed matriculation based on visual data obtained from Hot and Liputan Khusus rubrics, which is a representative edition of Dewi Magazine in 2015, 2016, 2017, and 2018. From these data, visual data categorization was compiled, one of which is the fashion style category. This fashion style was analyzed visually based on clothing silhouette, clothing pieces, clothing components (tops, bottoms, and overalls), and clothing elements (neckline/collar, hands, clothing length, bottom length, motifs, and colors). The types of clothing styles that were initially tested were androgyny, avant-garde, beatnik, belle epoque, chic, dandy, deconstructive, disco, ethnic, flapper, folklore, glam rock, goth, grunge, hippie, contemporary, neo-classic, new neo-classic look, new romantic, punk, steampunk, sporty, streetwear, surrealism, victoria, youthquake, sporty casual, feminine romantic, sexy alluring, classic elegant, exotic dramatic, and arty-off-beat styles. Based on the fashion style, five types of clothing styles with the highest frequency of occurrence were obtained, which are chic, classic elegant, glamrock, streetwear, and youthquake.

The amount of visual data obtained from Dewi Magazine varied each year, because it could be that in an edition there was no Hot and Liputan Khusus rubrics, or if there is an event not happening in Indonesia hence the data was not representative. Below is the presentation of data obtained from sources in the form of tables and line graphs.

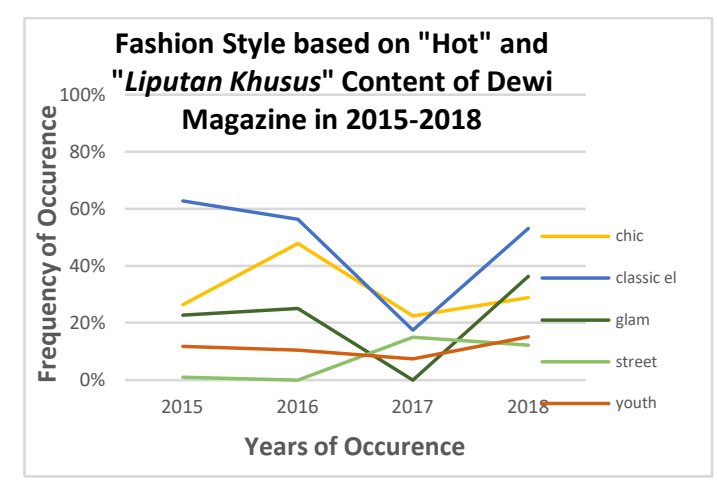


Fig. 2 Clothes Charts Based on the "Liputan Khusus" and "Hot" Rubrics of Dewi Magazine in 2015-2018

Based on the data obtained, classic elegant style was the style that most appeared compared to other fashion styles, with the percentage of occurrence above $50 \%$ in three years, except in 2017 that was decreased. The second highest frequency of occurrence was chic style, but none of them appeared to reach $50 \%$ or half of the sample, unlike the classic elegant style, as well as other styles. Only glamrock, streetwear, and youth wear styles that occurred between 5\%-36\%, the rest was only minor occurrences. The graph depicts that the occurrence of classic elegant style was almost similar in pattern to the glamrock style, having a consistency value in 2015, 2016, and 2018, but dropped in 2017. In 2017, the style with the highest frequency was chic, which, if examined had different characteristics with classic elegant style.

\section{TABLE 1}

Visual Data of Classic Elegant Style on Dewi Magazine 2015-2018

\begin{tabular}{|c|c|c|c|c|}
\hline $\begin{array}{l}\text { Ye } \\
\text { ar }\end{array}$ & $\begin{array}{c}\text { Classic elegant style } \\
\text { tracing }\end{array}$ & Description & $\begin{array}{c}\text { Classic elegant style } \\
\text { tracing }\end{array}$ & Description \\
\hline$\overbrace{\bar{n}}^{n}$ & 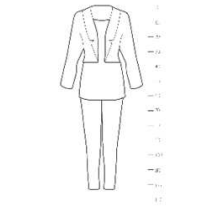 & $\begin{array}{l}\text { Name: Ira Lembong } \\
\text { Age range: } 31-40 \\
\text { Role: Socialite } \\
\text { Motive: Plain } \\
\text { Color: Black and white } \\
\text { Event: Photo session }\end{array}$ & 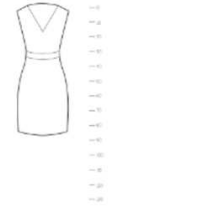 & $\begin{array}{l}\text { Name: Not mentioned } \\
\text { Age range: } 21-30 \\
\text { Role: Model } \\
\text { Motive: Plain } \\
\text { Color: Black } \\
\text { Event: Photo session }\end{array}$ \\
\hline กั & $\begin{array}{l}\vec{z} \\
\vec{z} \\
\vec{z}\end{array}$ & $\begin{array}{l}\text { Name: Bianca Belnadia } \\
\text { Age range: } 21-30 \\
\text { Role: Entrepreneur } \\
\text { Motive: Plain } \\
\text { Color: White } \\
\text { Event: Photo session }\end{array}$ & $\begin{array}{l}= \\
- \\
- \\
z \\
z\end{array}$ & $\begin{array}{l}\text { Name: Rosalyndinata } \\
\text { Gunawan (Ling-ling) } \\
\text { Age range: } 31-40 \\
\text { Role: Entrepreneur } \\
\text { Motive: Plain } \\
\text { Color: White } \\
\text { Event: Product launching }\end{array}$ \\
\hline$\overline{ }$ & D & $\begin{array}{l}\text { Name: Lilies } \\
\text { Wahjuningsih } \\
\text { Age range: } 31-40 \\
\text { Role: Socialite } \\
\text { Motive: Floral } \\
\text { Color: Black and white } \\
\text { Event: Anniversary }\end{array}$ & . & $\begin{array}{l}\text { Name: Dara Setyohadi } \\
\text { Age range: } 31-40 \\
\text { Role: Socialite } \\
\text { Motive: Plain } \\
\text { Color: Black and gray } \\
\text { Event: Book launching }\end{array}$ \\
\hline$\stackrel{\infty}{\text { กे }}$ & 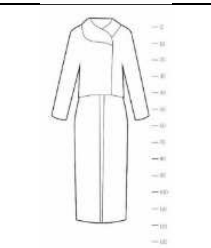 & $\begin{array}{l}\text { Name: Jasmine Prasetio } \\
\text { Age range: } 31-40 \\
\text { Role: Socialite } \\
\text { Motive: Kaleidoscope } \\
\text { Color: Black and white } \\
\text { Event: Boutique opening }\end{array}$ & 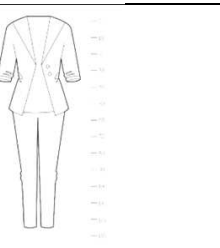 & $\begin{array}{l}\text { Name: Shanoon Hartono } \\
\text { Age range: } 41-50 \\
\text { Role: Socialite } \\
\text { Motive: Slightly baroque } \\
\text { Color: Black and white } \\
\text { Event: Boutique opening }\end{array}$ \\
\hline
\end{tabular}




\section{B. The Phenomenon of Fashion Trends in 2015-2018}

This research is focused on the period of 2015 to 2018. In that year, there were broadly a number of phenomena to be observed that are in accordance with cyclical or rotating trend patterns [11], which was the style from the 1980s. In that decade, the idea to start a better life emerged, one of which is to pay attention to health problems by starting to live a healthy lifestyle and exercise that is manifested in a fit body. To some people, when a healthy lifestyle cannot be fully applied, they tried to imitate it in a stylish manner as if it has been able to apply the pattern but only in appearance, such as wearing clothing with a silhouette that shows broad shoulders, and a sturdy and charismatic chest.

The tendency of the community, especially young people, was trying to transform their lives to become well-established, in response to the previous culture, namely the culture of hippies whose lifestyle was anti-establishment and tended to be self-destructive, with the use of addictive substances and alcoholic drinks. This appearance was supported by a strong desire to get a financially decent life, position, and dignity from a young age, known as Yuppies. Manifestations of fashion in this decade were elegant tailored suits and neat preppy styles. Yuppies or "Young, well-educated, well-paid urban professionals" referring to young people the age 28 - 35 that earned salary of more than $\$ 40,000$ per year and lived in metropolitan area. despite their expensive tastes, these professionals remained healthconscious with low-fat diets, all-natural fruit drinks, and bottled water. For exercise, they were often found jogging [12].

This phenomenon was almost similar to the 1980s which was captured in the trend of clothes in Indonesia. They paid attention to personal welfare first to be able to influence and prosper the others afterwards. This made them start paying attention to physical health by diligently exercising such as attending the gym, yoga, running, and other types of sports. This is related to the phenomenon of Fitspiration, an online trend designed to inspire viewers towards a healthier lifestyle by promoting exercise and healthy food [13]. A healthy body shape was no longer defined by a "skinny" body, which was definition of an ideal body shape for women in previous eras, but a fit body by showing large parts such as the arms, chest, and other body parts.

Today's young generation was also a generation of workers in the business sector, as well as working in offices with enough income to support their respective lifestyles. This pattern was similar to the cultural patterns of yuppies in the $80 \mathrm{~s}$, where the young people had a tendency to be able to live independently, had a high level of education, cared about issues that arouse in their place both in environmental, political, and social aspects. Based on research that has been done by Mary Alice Casto and Marilyn DeLong, the participants associated simple and understated layout and surface structures with classic, which allowed a design to express maturity and sophistication [14]. This generation also represented itself with neat, classic, and elegant clothing while still showing power and manners. Regis stated in his research, as appreciation of beauty shifted from the objective to the subjective, taste, as a special faculty, provided for a rational aesthetic judgment [15]. They try to show the character emphasizing on essence, and did not like excessive things, by more interested in using clothing with colors that were not too bright and tend to be monochrome.

The selection of classic elegant clothes with a dashing silhouette to women also showed the culture and movement of women empowerment that developed in Indonesia. Women demand gender equality in running their daily lives. As Duflo stated in her research, a key source of inequality between women and men stems from the way they are expected to spend their time [16]. Now, women can choose to carry out their activities as workers either at 
home, work or as a housewife. Classic elegant clothes could help women to gained confidence in their activities. The manifestation of this movement was the use of clothing with neat style such as wearing a blazer, tailored suits, and silhouettes that tend to be genderless. There were also the use of baggy pants, pipes, and culottes that represented flexibility and ease of movement. In terms of fashion accessories, the use of sports shoes such as sneakers and running shoes in daily life, whether sports or not, also reflected dynamism and a healthy lifestyle. DeLong stated, classic design has enough familiarity that its form and contexts are still readily understood but can be adjusted or embellished so that it has enough newness or novelty to induce a positive cognitive reassesment or esthetic response [14]. The elegant classic style could be a trend that sticks out in 2015-2018, but because of its timeless manifestations, it was very possible that this classic elegant style did not only appear due to collisions between phenomena, but rather became a long-term trend which could give birth to a new character in the style of upper-class consumers clothes in Indonesia. The idea that emerges is that the classic elegant style as a fashion trend is not only a choice for a society in a certain time, but represents how the social and cultural movements of the community, how they interpret a healthy lifestyle by using fashion as a showcase. The idea that emerged from this research was how the influence of the age movement of influencers influenced the adaptation of fashion styles in a period because of the phenomenon of the rising young billionaire.

\section{CONCLUSION}

The analyzed data shows that the average woman who wore classic elegant clothes was a woman with a professional background in celebrity, socialite, and entrepreneurship, who tended to have a profession that required high social interaction, meeting people from various circles, thus demanding to always appear impeccable. From the matrix, obtained demographics of women who wore the classic elegant style were women with a majority of ages of 20-40 years. Previously, the Yuppies style was used by women aged 28-35 years, now, due to the phenomenon of young billionaire, the trend of young people who were very well-established due to growing up in the internet era and having a profession that was attached to that era (selebgram, youtuber, content creator, and celebrities), causing many young women to use classic elegant style to attend number of events, and the classic elegant style was not only reaching women younger than the average Yuppie trend user in the 80s (28-35 years), but also the oldest age range shifts to age 40 , which happened due to the phenomenon of the ease of access of people with that age range to access technology, and to get information and preferences about the latest trends. Based on the process of collecting and arranging colors in the matrix, the four colors often appeared in various types of events to support the classic elegant style and to be more context-free because these colors could be used in a variety of settings.

\section{ACKNOWLEDGE}

This research was supported by Program Penelitian, Pengabdian kepada Masyarakat dan Inovasi (P3MI) LPPM ITB 2019. This research is a part of Doctoral research on Doctoral 
Programs Visual Art and Design, thus we would like to show our gratitude to the supervisors of the proccess.

\section{REFERENCES}

[1] M. Barnard, Fashion Sebagai Komunikasi. Jakarta: Jakasutra, 2011.

[2] B. Anas, Indonesia Indah “Batik.” Jakarta: yayasan Harapan Kita, 1997.

[3] M. . Zaman, 100 Tahun Mode di Indonesia 1901-2000. Jakarta: Meutia Cipta Sarana \& DPP Ikatan Busana Indonesia "Kartini," 2001.

[4] A. O'Cass, "Fashion Clothing Consumption: Antecedents and Consequences of Fashion Clothing Involvement," Eur. J. Mark., vol. 38, no. 7, pp. 869882, 2004.

[5] B. Berelson, Conten Analysis in Communication Research. New York: The Free Press, 1952.

[6] P. Mayring, Qualitative Content Analysis: Theoritical Foundation, Basic Procedures and Software Solution. Klagenfurt, 2014.

[7] T. . Midiani and dkk, Rencana Pengembangan Industri Mode Nasional 2015-2019. Jakarta: PT. Republik Solusi, 2015.

[8] P. Kristav, I. Bäckström, A. Nordin, A. Warell, and O. Diegel, "A MultiDimensional Framework for the Development of Authentic Consumer Products," J. Mark. Consum. Behav. Emerg. Mark., vol. 2/2018, no. 8, pp. 46-65, 2018.

[9] P. Wojciechowska, "Influence of personality on buying behaviour: a crosscultural study comparing Poland and the UK," J. Mark. Consum. Behav. Emerg. Mark., vol. 2017, no. 2, pp. 54-76, 2017.

[10] J. Galak, K. Gray, I. Elbert, and N. Strohminger, "Trickle-Down Preferences: Preferential Conformity to High Status Peers in Fashion Choices," PLoS One, vol. 11, no. 5, p. e0153448, 2016.

[11] B. Sproles, "Fashion Life Cycles Principles and," J. Mark., vol. 45, no. 4, pp. 116-124, 2010.

[12] M. Berman, The Eighties in America. Pasadena: Salem Press, Inc., 2008.

[13] M. Tiggemann and M. Zaccardo, "'Exercise to be fit, not skinny': The effect of fitspiration imagery on women's body image," Body Image, vol. 15, pp. 61-67, 2015.

[14] M. A. Casto and M. DeLong, "Exploring Esthetic Response to Classic as a Means to Slow Fashion," Fash. Pract., vol. 11, no. 1, pp. 105-131, 2019.

[15] T. Ferrero-Regis, "Fashion media: Past and present," Fash. Theory - J. Dress Body Cult., vol. 19, no. 4, pp. 445-451, 2015.

[16] E. Duflo, "Women empowerment and economic development," J. Econ. Lit., vol. 50, no. 4, pp. 1051-1079, 2012. 